\title{
How Partisan is the Press? Multiple Measures of Media Slant*
}

\author{
JOSHUA S. GANS \\ Rotman School of Management, University of \\ Toronto, Toronto, Ontario, Canada
}

\author{
ANDREW LEIGH \\ Economics Program, Research School of \\ Social Sciences, Australian National University, \\ ACT, Canberra, Australia
}

\begin{abstract}
We employ several different approaches to estimate the political position of Australian media outlets, relative to federal parliamentarians. First, we use parliamentary mentions to code over 100 public intellectuals on a left-right scale. We then estimate slant by using the number of mentions that each public intellectual receives in each media outlet. Second, we have independent raters separately code front-page election stories and headlines. Third, we tabulate the number of electoral endorsements that newspapers give to each side of politics in federal elections. Overall, we find that the Australian media are quite centrist, with very few outlets being statistically distinguishable from the middle of Australian politics. It is possible that this is because of the lack of competition in the Australian media market. To the extent that we can separate content slant from editorial slant, we find some evidence

that editors are more partisan than journalists.
\end{abstract}

\section{Introduction}

As the primary means through which politicians communicate with the electorate, a free and fair media is integral to a healthy democratic

* We have received valuable comments from associate editor Mardi Dungey, two anonymous referees, Tim Groseclose and seminar participants at the Australian National University and the 2008 Australasian Public Choice meetings. Vivienne Groves, Kimberley Jin, Rachael Meager, Susanne Schmidt, Michelle Tan and Elena Varganova provided outstanding research assistance. We are also grateful to those individuals who coded newspaper headlines and articles: David Christie, Chamath De Silva, Robert Macdonald, Christine Mahoney and Jimmy Phengrasmy.

JEL classifications: D72, L82

Correspondence: Joshua S. Gans, Rotman School of Management, University of Toronto, Toronto, Ontario, M5S 3E6, Canada. Email: joshua.gans@gmail.com system. ${ }^{1}$ It is, therefore, hardly surprising that journalists and politicians are acutely concerned about the political leanings of media outlets. Occasionally, media outlets boast of their influence, as with The Sun newspaper claiming the day after the Conservative victory in the 1992 UK

\footnotetext{
${ }^{1}$ Press freedom is enshrined in Article 19 of the Universal Declaration of Human Rights, which states: 'Everyone has the right to freedom of opinion and expression; this right includes freedom to hold opinions without interference and to seek, receive, and impart information and ideas through any media regardless of frontiers'. An annual 'Freedom of the Press Index' compiled by Freedom House tracks the extent to which media outlets are subject to overt political control, as well as the potential for ownership concentration to lead to bias. In the 2008 report, Freedom House rates the freedom of the press in Australia as 35 th out of 195 nations.
} 
election 'It's The Sun Wot Won It'. More frequently, politicians object to perceptions of favouritism, as when Barack Obama described Fox News in 2009 as 'one television station that is entirely devoted to attacking my administration'.

In this article, we focus on measuring media slant. We define a news outlet as being slanted if it gives more favourable coverage to one side of politics than the other. While measuring media slant is both important and policyrelevant, it is also empirically difficult. For example, most media outlets tend to provide a greater volume of coverage to the incumbent political party than to opposition political parties. We do not regard differences in the volume of coverage in itself as being a form of media slant. However, a media outlet that criticised all opposition proposals and praised all government announcements would be regarded as slanted.

In our view, a good measure of media slant ought to reflect the ideological affinity between a particular media outlet and one side of politics. In effect, such a measure plots media outlets onto the political spectrum, allowing us to answer questions like: 'If this newspaper were a politician, how would it vote?'

Note that we deliberately use the term 'media slant' instead of 'media bias', for the reason that our measures are relative rather than absolute. To see this, suppose that a political party were to publicly pronounce that the earth is flat. In this instance, one might expect that most - if not all - media outlets would denounce that political party, perhaps making unkind comments about the intellect and judgement of the party's leaders as they did so. If an election were in the offing, editorials in some newspapers might even opine that these pronouncements made the party unfit to govern. Such an event would not reflect media bias, as journalists are judging politicians statements against an absolute standard (scientific truth). However, it would be captured as a form of 'media slant'.

Relative to the previous literature, our article makes two main advances. The first relates to the methodology for estimating media slant. We introduce a new measure of media slant, based on the political positions of public intellectuals, which is different from those that have previously been used in the literature. For example, rather than using public intellectuals, Puglisi and Snyder (2010) estimated the relative political position of a media outlet by analysing the average difference between a newspaper's stance on ballot propositions and the public's stance as expressed through their votes. We then compare this measure with the results from other approaches, such as the political positions of think tanks (as used in Groseclose and Milyo, 2003), or the coding of articles. Another methodological contribution of our work is to separate the journalistic stance of a media outlet from its editorial stance.

Our second main contribution has to do with the structure of the media market. In our empirical analysis, we focus on Australia, in contrast with a literature that has previously been heavily focused on the United States. This has the advantage that it allows us to see the extent to which US findings can be generalised into other contexts, and study a media market that is more heavily concentrated.

Politically, Australia is a bicameral parliamentary democracy with single-member electorates in House of Representatives and multi-member electorates (with state/territory boundaries) in the Senate. There are 150 members of the House of Representatives and 76 senators. Voting is compulsory (with a fine of $\mathrm{A} \$ 20$, a little less than the median hourly wage), and ballots are counted using preferential voting (also known as instant runoff voting in the House of Representative and Single Transferrable Vote in the Senate). At the national level, there are effectively two political parties: the left-leaning Australian Labor Party, and a right-wing Coalition of the predominantly urban Liberal Party of Australia and the rural National Party of Australia. Party discipline is strong, and it is extremely rare for members to 'cross the floor' and vote with the opposing party. ${ }^{2}$ Our analysis focuses on the period 1996-2007, when the Coalition held office at the federal level.

Although two-party politics considerably simplifies our analysis, it is worth noting that it may have the effect of collapsing multi-dimensional differences into a single continuum. Although most of the differences in Australian politics can be mapped onto a standard leftright spectrum (e.g. size of government, level of labour market regulation), our approach does not allow for the possibility of a second axis

\footnotetext{
${ }^{2}$ Such strict party discipline means that there would be little point in constructing Poole-Rosenthal-type measures of the ideology of Australian legislators.
} 
(e.g. authoritarian versus libertarian). ${ }^{3}$ In practice, we believe that this is unlikely to be a problem, given that Australia has strong party discipline, and a much lower emphasis than in US politics on issues of personal liberty such as abortion, gun control or religious education.

To measure media slant, we use three approaches. Our main approach is to use the political positions of 'public intellectuals' (i.e. commentators and academics who are regularly quoted in both parliament and the press). Based upon positive mentions on the floor of parliament, we place each of the public intellectuals on the political spectrum. Based on mentions in the media, we then develop an aggregated index of the political position of each media outlet.

Our second measure of media slant relies on content analysis. After removing all identifying information (e.g. headline, newspaper name), we asked a team of people, which we refer to as 'coders', to rate - on a left/right scale - all front-page newspaper articles on political topics that appeared during the month before the 2004 Australian election. Combining these ratings provided us with a proxy for the media slant of major journalists at these newspapers.

Third, we estimate a measure of the media slant of editors. For this purpose, we asked the same team of coders to give a left/right rating to all front-page political stories in the 2004 election campaign. We also coded all newspaper editorials over this period, and counted the number of endorsements that each newspaper gave to each political party.

To summarise our results, we find that there is some dispersion of media slant in Australia when we use media mentions of public intellectuals. Interestingly, newspapers tend to be located to the left of that range, while talk-back radio and television are located to the right. Only 1 of the 27 outlets we study (ABC Channel 2 television news) is significantly distinguishable from the centre position. These results are robust to various specifications. We also find that there has been no systematic evolution in slant over time. To the extent that cross-country comparisons are possible, our results suggest that the overall

\footnotetext{
${ }^{3}$ The literature on political spectrums has proposed many dimensions, including tough/tender, pragmatic/ idealistic, rational/irrational and traditional/secular. However, most schemas include a standard left/right axis.
}

range of media slant is more concentrated than has been observed for the United States.

We also examine newspaper article content and find that in reporting the 2004 election, there is relatively little bias in that content. Similarly, in absolute terms the same can be said for article headlines (which are determined at an editorial level). On both content-coding metrics, only one outlet (The Age newspaper) is distinguishable from the centre position. The same, however, cannot be said for editorial endorsements that, interestingly, are highly correlated with observed bias in article headlines. This suggests that slant is determined at an editorial level rather than through pressure or article selection by journalists. We note that previous papers on media slant, such as Larcinese et al. (2011) and Puglisi and Snyder (2010), have not distinguished between the text and the headline of each article and, therefore, did not capture this nuance.

The remainder of this article is structured as follows. In Section II, we examine the literature relating media slant as a function of the degree of competition between media outlets in a market. In Section III, we present results using public intellectuals as a crosswalk from parliament to the press. In Section IV, we present results from content coding, and in Section V, we present results from coding headlines and editorials. The final section concludes.

\section{Media Slant and Competition}

Perhaps the most obvious difference between Australia and the United States where previous studies of media slant have been undertaken is the degree of media consolidation. In Australia, in major capital cities, there are two or three major newspapers and a limited variety of nonmusic radio outlets. ${ }^{4}$ This is in contrast to cities in the United States, which may have additional local and nation-wide newspapers and a host of both AM and FM radio outlets. 5

\footnotetext{
${ }^{4}$ For example, the CEO of the Canadian company that owns a majority stake in Channel 10 has described the Australian media market as 'structurally less competitive' than other markets (quoted in Tabakoff, 2009).

5 Australia's only national newspapers are The Australian and the Australian Financial Review. In contrast, the United States has not only USA Today and the Wall Street Journal, but also newspapers such as the New York Times and the Washington Post that are widely circulated across the nation.
} 
The key question is whether we expect competition between media outlets to impact on the degree of media slant. Basic industrial economics is divided on this issue. On the one hand, competition can generate increased variety. But variety is a double-edged sword. If consumers follow outlet bias, then Campante and Hojman's (2010) work suggests that this increased variety could increase voter polarisation. ${ }^{6}$ On the other hand, even where consumers have a range of beliefs, as exemplified by Hotelling's famous example, competition can lead to mimicry on the part of firms in the product positioning. Either way, media markets are a complex interaction between the outlets themselves, readers and advertisers, which makes the analysis of competition more challenging. Gentzkow et al. (2010) investigate the relationship between competition in the newspaper sector and the sector's influence on political outcomes, and find little evidence of any consistent or strong relationship.

Gentzkow and Shapiro (2006) consider a situation where news outlets are tempted to bias reporting towards the existing biases of their readers to be seen as a more credible information source in their eyes. This tends to increase bias in media reporting for a given outlet. Nonetheless, they demonstrate that competition between independent news outlets does reduce such bias. An independent source of information is a check on inaccurate reporting as the risk of being caught out and losing their reputation keeps news outlets more honest in their information provision. ${ }^{7}$ That said, it is also possible that readers, reports or governments might actually prefer biased reporting. Mullainathan and Shleifer (2005) show that when readers prefer their news biased, increased competition works to satisfy that demand; perhaps too much so, leading to more polarisation than is actually the case amongst the citizenry.

Thus, competition works to satisfy the preferences of readers. If readers demand truthful reporting, competition will assist in supplying that and media will be less biased. If readers do

\footnotetext{
${ }^{6}$ Campante and Hojman (2010) also identify a countervailing effect as increased media competition increases media access, which tends to lead to greater voter turnout from more moderate voters.

${ }^{7}$ Similarly, Anderson and McClaren (2009) demonstrate that bias engendered by the political preferences of media owners can be undone by competition.
}

not demand truthful reporting but prefer bias, competition will supply a biased media. What is true for the models presently in the literature is where the media is not profit-driven (e.g. is publicly owned), there should be no distortion. ${ }^{8}$ However, the potential bias in publicly operated media remains an open theoretical issue.

\section{Using Public Intellectuals to Estimate Media Slant}

In the US literature on media slant, two approaches that have been employed are to use think tanks as a crosswalk (Groseclose \& Milyo, 2005), and to use common phrases (Gentzkow \& Shapiro, 2008). For a relatively small country like Australia (with a population of 21 million), neither of these approaches are ideal. As Australia has relatively few think tanks, using them as a crosswalk would potentially make our results vulnerable to miscoding one or two think tanks (though we, nonetheless, present these results for the purpose of comparison). In the case of common phrases, there is considerably less 'message discipline' in Australia than in the United States. For example, Gentzkow and Shapiro (2008) discuss the way in which political strategists deliberately encouraged Republican representatives to use the phrases 'death tax', 'war on terror' and 'personal accounts' (in contrast, Democratic representatives were more likely to say 'estate tax', 'war in Iraq' and 'private accounts'). It is rare for Australian political parties to manage the language choice of their representatives to the same extent.

Other measures of media slant include airtime or focus given to politicians on either side of the political spectrum, which is the technique employed by Durante and Knight (2009) to investigate Italian media bias. Puglisi's (2011) study on the political slant of the New York Times employs a variation on this technique by measuring the focus given to issues on which one party is seen as more competent. Another technique, which is employed by Ansolabehere et al. (2006), is to track the explicit political endorsements of major newspapers. Ho and Quinn (2008) provide a variation on this by measuring newspaper endorsements of Supreme Court decisions in the United States.

\footnotetext{
${ }^{8}$ Baron (2006) examines what happens when there is journalistic bias. He demonstrates that such bias may not be removed by competition.
} 
Our approach is to use Australian public intellectuals as a crosswalk from parliament to the press. 'Public intellectual' is a somewhat loosely defined term, which we understand to mean individuals who are regarded as authorities on particular policy issues. This might include academics, think tank researchers, authors and former political advisers. ${ }^{9}$ As we did not wish to create our own ad hoc list of public intellectuals, we used a list compiled by the Sydney Morning Herald (Visontay, 2005). This comprised Australia's 'Top 100 Public Intellectuals', though because of a number of ties, the list included 127 names.

The Sydney Morning Herald's list of public intellectuals was compiled by asking 100 people 'from a broad range of academic, political, artistic, diplomatic, scientific, business and media backgrounds' to nominate 10 people each. ${ }^{10}$ These votes were then tallied to produce the final ranking. So far as we are aware, this is the most comprehensive list of public intellectuals that exists for Australia (other rankings, such as the Australian Financial Review's list of the 'ten most powerful people' are less appropriate for our purposes), while Barry Jones' 1993 list of 'Australia's 17 public intellectuals' is now somewhat dated. ${ }^{11}$

Scanning the list of names on the Sydney Morning Herald's list, we were somewhat concerned that it might under-represent right-wing

\footnotetext{
${ }^{9}$ Our study does not explicitly look at the role of economists as public intellectuals, but readers interested in that topic may appreciate Millmow (2005) and Millmow and Courvisanos (2007).

${ }^{10}$ The second-named author was one of the 100 voters for the Sydney Morning Herald. Unsurprisingly, omitting his votes from the final tally makes no tangible difference to the list.

${ }^{11}$ Barry Jones' 1993 list was: David Penington (Vice-Chancellor, Melbourne University), Mark Oliphant (physicist), 'Nugget' Coombs (economist), Davis McCaughey (church leader and former Governor of Victoria), John Passmore (philosopher), BA Santamaria (media commentator), Charles Birch (biologist), Zelman Cowen (former Governor-General), Donald Horne (author), Peter Karmel (educator), Hugh Stretton (writer), Leonie Kramer (educator), Geoffrey Blainey (historian), Gustav Nossal (medical biologist), Germaine Greer (writer), Michael Kirby (jurist) and Peter Singer (philosopher). Another source that future researchers might consider using is the list of attendees at the Australian Government's '2020 Summit'.
}

public intellectuals. Accordingly, we added to our list all the research staff of Australia's two largest right-wing think tanks: the Centre for Independent Studies and the Institute for Public Affairs. We show our results both including and excluding these 26 additional individuals. ${ }^{12}$

From the list of public intellectuals, we first omitted six individuals who are current or former members of state or federal parliament. ${ }^{13}$ This leaves us with a total of 147 names $(127+26-6)$. We then searched the federal parliamentary record (Hansard) for positive mentions of each of the public intellectuals by Coalition or Labor members of parliament. ${ }^{14}$ This involved a research assistant reading each of the Hansard references, and coding only those mentions that cast the public intellectual in a neutral or positive light. ${ }^{15} \mathrm{We}$ did not include mentions in which parliamentarians referred to public intellectuals in negative terms. An example of a quote that was not included in our study is the following, from Senator John Faulkner: ${ }^{16}$

People like Warren Entsch have attacked these distinguished Australians. And who do we finally have in the papers today? We get the real doddering fools like Paddy McGuinness, Piers Akerman and others trying to defend this government and attacking the record of these fine and distinguished Australians.

Of the 147 public intellectuals, 40 were never mentioned in parliament. The remaining 107 public intellectuals garnered a total of 1517

12 The Centre for Independent Studies (CIS) and Institute for Public Affairs (IPA) staff lists were as of 8 June 2007. Two CIS researchers - Helen Hughes and Owen Harries - were on the Sydney Morning Herald list, so we do not add them a second time (nor do we omit them for the purposes of the robustness check).

${ }^{13}$ The current or former politicians were Bob Brown, Bob Carr, Peter Coleman, John Hyde, Barry Jones and John Stone.

${ }^{14}$ Our search covered both chambers, but not committee hearings. The date range was January 1996 June 2007.

${ }^{15}$ Our list includes two people with the name Peter Saunders. At the time when we conducted our analysis, one worked at the University of New South Wales, while the other worked at the Centre for Independent Studies. We were careful to ensure that our coding instructions pointed this out, and that the two individuals were always distinguished.

${ }^{16}$ Senate Hansard, 10 August 2004. 
parliamentary mentions. However, the distribution of media mentions is quite skewed. Among public intellectuals who were mentioned once or more, the mean number of mentions is 14 and the median number of mentions is $6 .{ }^{17}$

Labor members of parliament were slightly more likely to mention public intellectuals on this list than were Coalition members of parliament. Across the public intellectuals, 47 per cent of the mentions were from Coalition politicians, while the remaining 53 per cent were from Labor MPs or senators. (The weighted mean is also 47 per cent.)

Naturally, with a small number of mentions, it is possible that a particular public intellectual might be mentioned more often by one side of politics merely by chance. For each public intellectual, we therefore estimate the two-sided $P$-value from a binomial probability test on the hypothesis that the public intellectual received 47 per cent of mentions from the Coalition (being the mean in the sample).

For 21 of the public intellectuals, the $P$-value on this test is less than 0.05 , suggesting that they are mentioned significantly more by one side of politics than the other. Among these, 10 public intellectuals are mentioned significantly more often by Labor parliamentarians: Larissa Behrendt, William Deane, Mick Dodson, Gerard Henderson, Michael Kirby, David Marr, Les Murray, Barbara Pocock, Anne Summers and George Williams. Eleven public intellectuals are mentioned significantly more often by Coalition parliamentarians: Marie Bashir, Geoffrey Blainey, Ron Brunton, John Hirst, Helen Hughes, Paul Kelly, Hugh Mackay, Wendy McCarthy, Noel Pearson, Ken Phillips and Paul Sheehan. A full list of the public intellectuals may be found in Table A1.

Beginning with the 107 public intellectuals who received at least one mention in parliament, we then carried out a search of the Australian media for all instances in which each individual was mentioned in a particular media outlet. We chose to search across 10 newspapers (Austra-

\footnotetext{
17 The public intellectuals who are most often mentioned in Hansard are Michael Kirby (137 mentions), Noel Pearson (135 mentions) and William Deane (109 mentions). As an anonymous referee noted, our most cited public intellectuals contain a significant number of people who speak and write primarily on Indigenous issues (the 10 most cited in Hansard include Noel Pearson, Mick Dodson and Frank Brennan).
}

lian Financial Review, Canberra Times, Sydney Morning Herald, The Age, The Australian, Tabloids, Daily Telegraph, Herald Sun, The Advertiser, The Courier Mail and The West Australian), 12 radio stations (Sydney 2UE, Sydney 2GB, Sydney ABC 702, Perth 6PR, Perth ABC 720, Melbourne 3AW, Melbourne ABC 774, Adelaide 5AA, Brisbane 4BC, ABC Radio National, ABC 891 Adelaide and Brisbane $\mathrm{ABC}$ 612) and 5 television stations (Channels 7, 9, 10, ABC and SBS). In the case of newspapers and radio stations, we coded all content, while in the case of television, we only coded the evening news broadcasts. With the exception of the Australian Financial Review, all searches were carried out by Media Monitors, whose database contains full text of newspapers and summaries of broadcasts. All media searches cover the period $1999-2007 .{ }^{18}$ In total, we recorded 84,113 media mentions of the public intellectuals in our sample. ${ }^{19}$

Our newspapers are chosen because they are the largest in Australia, covering a mix of broadsheet and tabloids. In the case of radio, we chose the main public broadcaster (the ABC) and included $\mathrm{ABC}$ Radio National, plus the $\mathrm{ABC}$ stations in Australia's five largest cities. We then chose the major talk radio stations in those cities. For television, we chose the evening news broadcasts on the largest television stations, which include two public broadcasters: a mainstream station (ABC), and a public broadcaster with a mandate to focus on broadcasts that 'reflect Australia's multicultural society' (SBS).

As we are using a Media Monitors database (necessary if we are to include radio and television), the media records include total mentions, which may be positive and negative. Although this could, in principle, cause us to erroneously include negative mentions, newspaper searches suggested to us that it was extremely rare for a

\footnotetext{
${ }^{18}$ Owing to data limitations, we are not able to search further back than this for most publications; however, our results are robust to dropping Hansard searches for 1996-1998.

${ }^{19}$ The 10 public intellectuals who are most often mentioned in the media (and their corresponding media mentions) are: George Pell (3698), Michael Duffy (3251), David Williamson (2896), Barry Humphries (2845), Michael Kirby (2750), Phillip Adams (2677), Germaine Greer (2494), Peter Carey (2363), Mark Davis (2340) and Noel Pearson (2229).
} 
media outlet to mention a public intellectual in a negative manner. Although politicians sometimes attack public intellectuals, virtually all mentions of public intellectuals in media outlets are neutral or positive.

To estimate the political position of each media outlet, we effectively wish to ask the question: which media outlets cited the kinds of public intellectuals who were also cited by the Coalition in parliament? One way to think about this is that it involves collapsing a threedimensional dataset (public intellectuals $\times$ media outlets $\times$ time) into a two-dimensional dataset (media outlets $\times$ time). We do this by estimating a weighted ordinary least squares (OLS) regression, in which the dependent variable $P$ is the share of Coalition mentions by a given public intellectual $i$ in media outlet $j$ in time period $t$, and the independent variable is a vector of indicator variables for each media outlet:

$$
P_{i j t}=\sum_{j=0}^{J} I_{j t} .
$$

We are now left with the question of how to choose an optimal weighting scheme for aggregating parliamentary mentions and media mentions. Clearly, these weights should be an increasing function of the number of parliamentary mentions (as frequent mentions in parliament increase the precision with which we can estimate a public intellectual's ideological position), and an increasing function of the number of media mentions (as media outlets who mention a given public intellectual more frequently are demonstrating their preference for that individual).

We opt to use a weighting scheme that is the product of the square root of the number of parliamentary mentions and the number of media mentions. Where $p$ is the number of parliamentary mentions received by public intellectual $i$ in period $t$ and $m$ is the number of media mentions given to public intellectual $i$ in media outlet $j$ in period $t$, the weight $w$ given to a particular observation is:

$$
w_{i j t}=\sqrt{p_{i t}} \sqrt{m_{i j t}} .
$$

Using square root weights has the advantage that (unlike log weights), the weights are still defined for observations with zeros. It also captures the intuition that the standard error of the mean of a binomial variable is equal to the square root of the sample size, multiplied by the mean, multiplied by 1 minus the mean, that is, $\mathrm{SE}=[n p(1-p)]^{0.5}$.

Aggregating media mentions in this manner allows us to give each media outlet a simple scale. Recall that the average public intellectual received 47 per cent of mentions from Coalition members of parliament. Thus, an outlet with a score of 0.47 evenly allocates its time across Coalition-favoured and Labor-favoured public intellectuals. An outlet with a score above 0.47 is more inclined to give time to Coalitionfavoured intellectuals, while an outlet with a score below 0.47 is inclined to give more time to Labor-favoured intellectuals.

We begin by estimating aggregated rankings for the entire time period. Table 1 presents our estimates of the political position of each of the media outlets in our sample, along with the standard error of that estimate and the number of public intellectuals mentioned by that outlet (naturally, outlets with more mentions have smaller standard errors). The main estimate uses all public intellectuals. All but one media outlet is within two standard errors of the centre position, 0.47 . On this metric, the only media outlet that is significantly slanted is ABC Channel 2 television news, which is significantly proCoalition during the period in question. However, even here the difference is relatively small, with the estimate for $\mathrm{ABC}$ television news being $0.51 .^{20}$

Several other interesting patterns can be seen in the data. As a group, newspapers tend to be more pro-Labor than radio and television stations. Of the 27 outlets listed in Table 1, the seven most pro-Labor outlets are newspapers. At the other end of the spectrum, television and talk radio tend to dominate, with the seven most pro-Coalition outlets being of these two types. One possible interpretation of this is that it reflects an underlying ideological slant across these different media. However, it is also conceivable that this is partly because of our

\footnotetext{
${ }^{20}$ One possible reason for this is that the $\mathrm{ABC}$ faces considerably greater scrutiny than other outlets over its political slant. With a Coalition government in power, this scrutiny may have led to the outlet featuring more of the public intellectuals who were also cited by Coalition parliamentarians. An alternative possibility is that the $\mathrm{ABC}$ result is merely because of chance (with 20 outlets, we would expect one to be significant at the 5 per cent level).
} 
TABLE 1

Media Slant Using Public Intellectuals (Main Estimate). Larger Numbers Denote a More Pro-Coalition Outlet (0.47 Denotes Equality). Outlets are Ranked in Ascending Order of Slant

\begin{tabular}{|c|c|c|c|}
\hline & Estimate & SE & $\begin{array}{l}\text { Total mentions of } \\
\text { public intellectuals }\end{array}$ \\
\hline Australian Financial Review & 0.436 & 0.027 & 1700 \\
\hline Canberra Times & 0.461 & 0.014 & 4916 \\
\hline Sydney Morning Herald & 0.462 & 0.011 & 16,175 \\
\hline The West Australian & 0.462 & 0.018 & 2352 \\
\hline Herald Sun & 0.466 & 0.015 & 5073 \\
\hline The Age & 0.466 & 0.012 & 10,499 \\
\hline The Advertiser & 0.468 & 0.017 & 4485 \\
\hline ABC Radio National & 0.47 & 0.021 & 1410 \\
\hline Daily Telegraph & 0.477 & 0.015 & 5597 \\
\hline Sydney ABC 702 & 0.478 & 0.02 & 2249 \\
\hline SBS News & 0.48 & 0.035 & 250 \\
\hline The Australian & 0.485 & 0.01 & 16,934 \\
\hline ABC 891 Adelaide & 0.486 & 0.026 & 590 \\
\hline Sydney 2UE & 0.486 & 0.029 & 387 \\
\hline Perth ABC 720 & 0.489 & 0.026 & 483 \\
\hline Channel 10 News & 0.49 & 0.029 & 275 \\
\hline The Courier Mail & 0.493 & 0.013 & 6359 \\
\hline Melbourne ABC 774 & 0.499 & 0.024 & 972 \\
\hline Sydney 2GB & 0.501 & 0.032 & 402 \\
\hline Brisbane ABC 612 & 0.504 & 0.026 & 489 \\
\hline Melbourne $3 \mathrm{AW}$ & 0.509 & 0.036 & 234 \\
\hline ABC Channel 2 News & $0.511 * *$ & 0.021 & 940 \\
\hline Adelaide 5AA & 0.513 & 0.038 & 257 \\
\hline Channel 9 News & 0.516 & 0.03 & 423 \\
\hline Perth 6PR & 0.516 & 0.034 & 251 \\
\hline Channel 7 News & 0.519 & 0.033 & 269 \\
\hline Brisbane $4 \mathrm{BC}$ & 0.524 & 0.045 & 142 \\
\hline Mean & 0.482 & 0.021 & 3129 \\
\hline
\end{tabular}

Note: ** Denotes that the outlet's estimate is significantly different from 0.47 , at the 5 per cent significance level.

approach for measuring slant (e.g. perhaps rightwing intellectuals are more telegenic than leftwing intellectuals).

Another pattern is a slight tendency for ideological clustering by radio stations in the same local market. While the overall standard deviation of the media slant estimate is 0.016 across all radio stations, the within-city standard deviation is somewhat smaller, at 0.014 . However, it is not clear from this result whether the local $\mathrm{ABC}$ radio stations are shifting towards their commercial counterparts, whether the commercial stations are shifting towards the $\mathrm{ABC}$ stations or whether both are tailoring themselves to local attitudes.

How do our estimates of media slant for Australia differ from those for the United States? Using think tanks as a crosswalk between Congress and the media, Groseclose and Milyo (2005) find a statistically significant degree of slant in all 20 media outlets that they study (18 were to the left of the median member of Congress and 2 to the right). ${ }^{21}$ It is possible that this is partly a function of methodology: Groseclose and Milyo use think tanks rather than public intellectuals, and code ideology using a continuous rather than dichotomous variable. ${ }^{22}$ However, it is also conceivable that our results

\footnotetext{
${ }^{21}$ The other major economics study of US media slant (Gentzkow \& Shapiro, 2010) does not report the share of newspapers in the analysis that are statistically distinguishable from the centre position.

${ }^{22}$ Specifically, Groseclose and Milyo (2005) use the ideology scores assigned to each legislator by the Americans for Democratic Action (ADA). Given that Australia has relatively few think tanks and strong party discipline, it is not feasible for us to precisely replicate the Groseclose-Milyo approach.
} 
TABLE 2

Media Slant Using Public Intellectuals (Alternative Specifications). Larger Numbers Denote a More Pro-Coalition Outlet (0.47 Denotes Equality). Outlets are Ranked in Alphabetical Order, by Group

\begin{tabular}{|c|c|c|c|c|c|c|c|c|}
\hline & $\begin{array}{l}\text { Main estimate } \\
\text { (from Table 1) }\end{array}$ & SE & $\begin{array}{l}\text { Omitting } \\
\text { columnists }\end{array}$ & SE & $\begin{array}{l}\text { Omitting } \\
\text { CIS/IPA }\end{array}$ & SE & $\begin{array}{c}\text { Significant } \\
\text { partisans only }\end{array}$ & SE \\
\hline \multicolumn{9}{|l|}{ Newspapers } \\
\hline Australian Financial Review & 0.436 & 0.027 & 0.437 & 0.027 & 0.433 & 0.028 & 0.421 & 0.062 \\
\hline Canberra Times & 0.461 & 0.014 & 0.461 & 0.013 & 0.46 & 0.014 & 0.444 & 0.032 \\
\hline Daily Telegraph & 0.477 & 0.015 & 0.47 & 0.015 & 0.476 & 0.015 & 0.455 & 0.036 \\
\hline Herald Sun & 0.466 & 0.015 & 0.466 & 0.015 & 0.463 & 0.016 & 0.44 & 0.038 \\
\hline Sydney Morning Herald & 0.462 & 0.011 & 0.468 & 0.011 & 0.46 & 0.012 & 0.444 & 0.026 \\
\hline The Advertiser & 0.468 & 0.017 & 0.467 & 0.017 & 0.467 & 0.018 & 0.432 & 0.044 \\
\hline The Age & 0.466 & 0.012 & 0.481 & 0.012 & 0.464 & 0.013 & 0.451 & 0.029 \\
\hline The Australian & 0.485 & 0.01 & 0.42 & 0.011 & 0.484 & 0.01 & 0.478 & 0.024 \\
\hline The Courier Mail & 0.493 & 0.013 & 0.493 & 0.013 & 0.49 & 0.014 & 0.489 & 0.031 \\
\hline The West Australian & 0.462 & 0.018 & 0.462 & 0.017 & 0.46 & 0.019 & 0.441 & 0.043 \\
\hline Newspaper mean & 0.47 & 0.014 & 0.464 & 0.014 & 0.468 & 0.015 & 0.451 & 0.035 \\
\hline \multicolumn{9}{|l|}{ Radio stations } \\
\hline ABC 891 Adelaide & 0.486 & 0.026 & 0.486 & 0.025 & 0.484 & 0.027 & 0.489 & 0.062 \\
\hline ABC Radio National & 0.47 & 0.021 & 0.47 & 0.02 & 0.466 & 0.022 & 0.465 & 0.047 \\
\hline Adelaide 5AA & 0.513 & 0.038 & 0.513 & 0.037 & 0.509 & 0.039 & 0.507 & 0.085 \\
\hline Brisbane 4BC & 0.524 & 0.045 & 0.524 & 0.044 & 0.523 & 0.047 & 0.558 & 0.144 \\
\hline Brisbane ABC 612 & 0.504 & 0.026 & 0.504 & 0.026 & 0.502 & 0.027 & 0.522 & 0.058 \\
\hline Melbourne 3AW & 0.509 & 0.036 & 0.509 & 0.035 & 0.507 & 0.037 & 0.515 & 0.079 \\
\hline Melbourne ABC 774 & 0.499 & 0.024 & 0.499 & 0.024 & 0.496 & 0.025 & 0.521 & 0.055 \\
\hline Perth 6PR & 0.516 & 0.034 & 0.516 & 0.033 & 0.514 & 0.035 & 0.53 & 0.078 \\
\hline Perth ABC 720 & 0.489 & 0.026 & 0.489 & 0.025 & 0.487 & 0.027 & 0.507 & 0.059 \\
\hline Sydney 2GB & 0.501 & 0.032 & 0.501 & 0.031 & 0.499 & 0.033 & 0.483 & 0.074 \\
\hline Sydney $2 \mathrm{UE}$ & 0.486 & 0.029 & 0.486 & 0.029 & 0.485 & 0.031 & 0.481 & 0.064 \\
\hline Sydney ABC 702 & 0.478 & 0.02 & 0.478 & 0.019 & 0.477 & 0.021 & 0.483 & 0.044 \\
\hline Radio mean & 0.493 & 0.028 & 0.493 & 0.027 & 0.491 & 0.029 & 0.5 & 0.065 \\
\hline \multicolumn{9}{|l|}{ Television stations } \\
\hline ABC Channel 2 News & 0.511 & 0.021 & 0.511 & 0.02 & 0.51 & 0.021 & 0.526 & 0.044 \\
\hline Channel 10 News & 0.49 & 0.029 & 0.49 & 0.029 & 0.49 & 0.031 & 0.498 & 0.061 \\
\hline Channel 7 News & 0.519 & 0.033 & 0.519 & 0.032 & 0.517 & 0.034 & 0.526 & 0.072 \\
\hline Channel 9 News & 0.516 & 0.03 & 0.516 & 0.029 & 0.515 & 0.031 & 0.53 & 0.068 \\
\hline SBS News & 0.48 & 0.035 & 0.48 & 0.034 & 0.477 & 0.036 & 0.498 & 0.078 \\
\hline Television mean & 0.505 & 0.028 & 0.505 & 0.027 & 0.504 & 0.029 & 0.517 & 0.062 \\
\hline
\end{tabular}

reflect the lack of competition in the Australian media market.

In Table 2, we show a number of alternative specifications, which we compare against the main estimate (shown in Table 1). The first check omits public intellectuals who write regular op-ed columns from the estimate of that outlet's slant. This makes little difference to any outlet except The Australian newspaper, which appears considerably more pro-Labor if its columnists are omitted. ${ }^{23}$

\footnotetext{
${ }^{23}$ This is almost entirely because of the fact that Noel Pearson, who received more media mentions than any public intellectual except Michael Kirby, is a columnist at The Australian newspaper.
}

Naturally, omitting newspaper columnists makes no difference to the rankings of radio and television (although it occasionally has a trivial impact on the standard error of those estimates).

The second check drops the public intellectuals from two right-wing think tanks (the Centre for Independent Studies and the Institute of Public Affairs) that we added to the Sydney Morning Herald list of public intellectuals. The third specification check uses only the 21 public intellectuals (listed before) who are mentioned significantly more often by one side of politics than the other. Again, these different approaches make little difference to the main results. 
TABLE 3

Comparing Producer and Consumer Ideology. Larger Numbers Denote a More Pro-Coalition Outlet (0.47 Denotes Equality)

\begin{tabular}{|c|c|c|c|c|}
\hline & $\begin{array}{l}\text { Slant estimate } \\
\text { by medium }\end{array}$ & SE & $\begin{array}{l}\text { Share who followed } \\
\text { election } 2004 \text { via } \\
\text { this medium }\end{array}$ & $\begin{array}{l}\text { Share following election } 2004 \text { with } \\
\text { this medium who voted for the } \\
\text { Coalition }\end{array}$ \\
\hline Newspaper & 0.471 & 0.004 & 0.150 & 0.498 \\
\hline Radio & 0.492 & 0.008 & 0.130 & 0.442 \\
\hline TV & 0.505 & 0.012 & 0.263 & 0.534 \\
\hline Mean & 0.483 & 0.007 & - & 0.549 \\
\hline
\end{tabular}

Note: Columns (3) and (4) are derived from the 2004 Australian Election Study. Column (3) is those who say that they used the media 'a great deal' to follow election 2004 (categories are not mutually exclusive). Vote is the House of Representatives vote, accounting for preferences. Mean includes respondents who did not use the media a great deal to follow the election.

We also analyse results for two time periods: 1999-2002 and 2003-2007. ${ }^{24}$ This allows us to test whether media slant has changed over time in Australia. The point estimates for the changes are small, and in all cases the standard error is larger than the magnitude of the change (results available on request).

To what extent are media outlets' political positions a function of the ideology of their audience? To test this, we re-estimated the results in Table 1 separately for each medium (newspapers, radio and television). Aggregating at this level allows us to get a more precise estimate of ideology. The results from this exercise are presented in Table 3. Across media types, only newspapers are centrist. Radio and television (taking all stations together in each case) seem to be pro-Coalition, as we can reject at the 1 per cent significance level the hypothesis that the slant equals 0.47 .

Using the 2004 Australian Election Study, we analyse the political preferences of voters who followed the election by newspapers, radio or television. On average, 54.9 per cent of respon-

\footnotetext{
${ }^{24}$ Our media citations are only broken into two time periods for cost reasons. As Media Monitors searches have to be manually entered into the database, searching for 107 public intellectuals across 27 media outlets required 2889 separate searches to be carried out for each time period. Our analysis requested that this be performed twice, by searching for each public intellectual in each media outlet in 1999-2002 and 2003-2007. This amounted to 5778 separate searches, which were each manually entered, and the results tabulated in a spreadsheet. Had we opted for annual searches, it would have necessitated 26,001 separate searches, which would have cost $4 \frac{1}{2}$ times as much.
}

dents in the Australian Election Study said that they voted for the Coalition (slightly above the true national figure of 52.7 per cent). However, the share of Coalition voters among those who got political news from newspapers is just 49.8 per cent, and the share among those who got political news from radio was 44.2 per cent. Controlling for factors such as age, gender and income makes no qualitative difference to this result. Thus, when measured by content, the ordering of the three media (from most leftwing to most right-wing) is newspapers, radio and television. When measured by consumer preferences, the ordering of the three media is radio, newspapers and television.

\section{Coding Article Content}

Another way that one can determine media slant is to directly analyse the content of articles. To assess this, we compiled a large file containing all the front-page political stories published in nine newspapers during the 2004 election campaign. ${ }^{25}$ In Australia, election campaigns last from the date on which the election is called until polling day, which in this case was 29 August to 9 October 2004.

Our sample consisted of 284 articles, which were rated by five independent coders. We asked each coder to rate the article on a 5-point scale:

1 Very pro-Labor

2 Somewhat pro-Labor

3 Middle of the road

4 Somewhat pro-Coalition

5 Very pro-Coalition

\footnotetext{
25 This part of our analysis did not include the Australian Financial Review.
} 
TABLE 4

Ratings of Front-Page Political Articles from the 2004 Federal Election. Larger Numbers Denote a More Pro-Coalition Outlet

\begin{tabular}{|c|c|c|c|c|}
\hline & \multicolumn{2}{|c|}{$\begin{array}{l}\text { Article coding results: articles coded from } 1 \\
\text { (very pro-Labor) to } 5 \text { (very pro-Coalition) }\end{array}$} & \multicolumn{2}{|c|}{ Existing metrics of article bias } \\
\hline & Mean & SE & $\begin{array}{c}\text { Journalist } \\
\text { survey (1992) }\end{array}$ & $\begin{array}{c}\text { Bias-o-meter } \\
\text { (2007) }\end{array}$ \\
\hline Australian Financial Review & & & 3.17 & 0 \\
\hline Canberra Times & 3.041 & 0.082 & 2.86 & -1 \\
\hline Daily Telegraph & 3.040 & 0.096 & 2.98 & 5 \\
\hline Herald Sun & 2.964 & 0.144 & 3.44 & 3 \\
\hline Sydney Morning Herald & 3.044 & 0.085 & 3.11 & -2 \\
\hline The Advertiser & 3.094 & 0.116 & 3.62 & 4 \\
\hline The Age & $2.751 * * *$ & 0.071 & 2.73 & -3 \\
\hline The Australian & 2.966 & 0.060 & 3.19 & 5 \\
\hline The Courier Mail & 2.907 & 0.087 & 3.16 & 3 \\
\hline The West Australian & 3.023 & 0.094 & 3.73 & 8 \\
\hline Mean & 2.963 & 0.083 & 3.20 & 2.2 \\
\hline
\end{tabular}

Notes: In the article coding, $* * *$ indicates that the newspaper's mean score is significantly different from 3 , at the 1 per cent significance level. Journalist survey ranges from 1 (very Labor) to 5 (very Liberal). Bias-o-meter estimate ranges from -10 (far left) to 10 (far right).

Sources: Article coding, authors' calculations, journalist survey from Henningham (1995); Crikey bias-o-meter from Simons (2007).

Our full instructions to coders are set out in the Appendix.

To check whether coders agreed with one another, we calculated the pairwise correlation between all possible pairs of coders (with 5 coders, there are 10 possible pairs). The correlations ranged from 0.32 to 0.60 , with a mean of 0.48 . This suggests that there was a reasonably high degree of consensus between the coders.

As in the previous section, we simply calculate the political position of each media outlet by estimating an OLS regression, in which the dependent variable is the rating of a given article by a particular coder. As all coders looked at all articles, the regression is unweighted.

The results are shown in Table 4. Across the nine newspapers, the mean article rating is close to 3 (being middle-of-the-road). The only newspaper whose mean score is significantly different from the three is The Age, which is rated by our coders as tending slightly proLabor. However, even in this case, the differences are quite slight. Pooling the five raters, 12 per cent of articles in The Age were regarded as very pro-Labor, 28 per cent as somewhat pro-Labor, 37 per cent as middle of the road, 18 per cent as somewhat pro-Coalition and 5 per cent as very pro-Coalition. A full breakdown of the coding is presented in Table A2.

We are aware of two other measures of journalistic slant, which are also presented in Table 4. The first is a survey conducted by John Henningham in 1992, published as Henningham (1995). That survey asked 1068 journalists the question: 'Thinking only of news and feature content, how would you rate the party political bias, if any, of the following'. Respondents were given five options: Very Labor, Slightly Labor, Middle of Road, Slightly Liberal and Very Liberal. These were coded from 1 to 5 , and thus correspond with our article coding.

The other measure is a 'bias-o-meter' compiled by media commentator Margaret Simons (2007), and published in the online newsletter Crikey.com.au. Newspapers were rated on a scale that ostensibly ran from -10 to +10 , although in fact the spread was only from -3 to +8. As with the other metrics used in this article, higher numbers denote newspapers that Simons regards as more favourable to the Coalition.

These three measures correlate quite well with one another. The correlation between the article 
TABLE 5

Editorial Slant

\begin{tabular}{|c|c|c|c|c|c|}
\hline & \multicolumn{2}{|c|}{$\begin{array}{l}\text { Ratings of political headlines from the } 2004 \\
\text { federal election: headlines coded from } 1 \\
\text { (very pro-Labor) to } 5 \text { (very pro-Coalition) }\end{array}$} & \multicolumn{3}{|c|}{ Editorial endorsements, 1996-2007 } \\
\hline & Mean & SE & Coalition & Labour & Share coalition \\
\hline Australian Financial Review & & & 5 & 0 & 1 \\
\hline Canberra Times & 2.871 & 0.081 & 0 & 2 & 0 \\
\hline Daily Telegraph & 2.872 & 0.095 & 3 & 2 & 0.6 \\
\hline Herald Sun & 3.218 & 0.143 & 5 & 0 & 1 \\
\hline Sydney Morning Herald & 3.025 & 0.084 & 3 & 1 & 0.75 \\
\hline The Advertiser & 3.094 & 0.115 & 5 & 0 & 1 \\
\hline The Age & $2.831 * *$ & 0.071 & 3 & 1 & 0.75 \\
\hline The Australian & 3.037 & 0.059 & 3 & 1 & 0.75 \\
\hline The Courier Mail & 2.880 & 0.087 & 4 & 1 & 0.8 \\
\hline The West Australian & 3.100 & 0.093 & 5 & 0 & 1 \\
\hline Mean & 2.968 & 0.082 & 3.6 & 0.8 & 0.765 \\
\hline
\end{tabular}

Note: In the headline coding, ** indicates that the newspaper's mean score is significantly different from 3 , at the 5 per cent significance level.

coding and journalist survey is 0.50 ; the correlation between the article coding and the biaso-meter is 0.41 , and the correlation between the journalist survey and the bias-o-meter is 0.72 .

\section{$V$ Coding Editorial Slant}

Although many studies make no distinction between journalistic slant and editorial slant, there is some reason to imagine that the two might diverge. ${ }^{26}$ Journalists are more likely to be in contact with one another, which may lead to a similar way of thinking. Conversely, editors are more likely to be in contact with proprietors, which may engender biases of its own. However, as editors hire and manage journalists, there is a limit to the extent to which the two groups can diverge from one another within a single publication.

To code editorial slant, we use two approaches. First, we use the same methodology as in coding articles to estimate the slant of front-page headlines. These headlines are chosen by editors rather than journalists. Perhaps because headlines are shorter than articles, our coders were more likely to agree with one

${ }^{26}$ As a referee pointed out to us, a famous example is the Wall Street Journal, which (anecdotally, at least) appears to have more political balance in its news pages than on its editorial pages. another when coding headlines than when coding articles. While the mean inter-rater correlation for articles is 0.48 , it is 0.61 for headlines (ranging from 0.51 to 0.74 across the 10 combinations of coder pairs). Notably, the inter-rater correlation for a given article or headline is higher than the correlation for the article and headline combined, on a given story. For each rater, we estimated the correlation between how $\mathrm{s} /$ he coded the article and how s/he coded the headline of that same story. These correlations ranged from 0.30 to 0.59 with a mean of 0.44 . In other words, a rater's coding of a given article tends to be closer to another rater's coding of the same article than to that rater's coding of the corresponding headline. This supports the notion that article slant and editorial slant may not always coincide precisely.

Table 5 presents the results from our headline coding exercise. For most newspapers, the mean is statistically indistinguishable from 3 (suggesting that the average headline during the 2004 election campaign is classified as ideologically middle of the road). The only exception is The Age, whose headlines are classified as significantly pro-Labor (at the 5 per cent significance level).

Our second measure of editorial slant is editorial endorsements in the five federal elections from 1996 to 2007. As newspapers do not 
TABLE 6

Financial Flows and Media Slant. Outlets are Ranked in Alphabetical Order, by Group.

\begin{tabular}{|c|c|c|c|c|c|}
\hline & \multirow{2}{*}{$\begin{array}{l}\text { Media slant } \\
\text { estimate } \\
\text { (from } \\
\text { Table 1) }\end{array}$} & \multicolumn{2}{|c|}{ Media donations to political parties } & \multicolumn{2}{|c|}{$\begin{array}{l}\text { Advertising expenditure by } \\
\text { political parties }\end{array}$} \\
\hline & & $\begin{array}{c}\text { Difference: } \\
\text { Coalition - Labor }\end{array}$ & $\begin{array}{c}\text { Ratio: } \\
\text { Coalition/Labor }\end{array}$ & $\begin{array}{c}\text { Difference: } \\
\text { Coalition - Labor }\end{array}$ & $\begin{array}{c}\text { Ratio: } \\
\text { Coalition/Labor }\end{array}$ \\
\hline \multicolumn{6}{|l|}{ Newspapers } \\
\hline $\begin{array}{l}\text { Australian Financial } \\
\text { Review }\end{array}$ & 0.436 & $\$ 20,300.00$ & 2.624 & $\$ 0.00$ & \\
\hline Canberra Times & 0.461 & & & $-\$ 18,000.00$ & 0.525 \\
\hline Daily Telegraph & 0.477 & $\$ 17,200.00$ & 4.440 & $-\$ 57,300.00$ & 0.509 \\
\hline Herald Sun & 0.466 & $\$ 17,200.00$ & 4.440 & $-\$ 21,100.00$ & 0.807 \\
\hline Sydney Morning Herald & 0.462 & $\$ 20,300.00$ & 2.624 & $-\$ 114,000.00$ & 0.575 \\
\hline The Advertiser & 0.468 & $\$ 14,700.00$ & 2.960 & $\$ 21,552.26$ & 2.821 \\
\hline The Age & 0.466 & $\$ 20,300.00$ & 2.624 & $-\$ 16,400.00$ & 0.863 \\
\hline The Australian & 0.485 & $\$ 17,200.00$ & 4.440 & $\mathrm{~N} / \mathrm{A}$ & $\mathrm{N} / \mathrm{A}$ \\
\hline The Courier Mail & 0.493 & $\$ 17,200.00$ & 4.440 & $\$ 2,732.16$ & 1.657 \\
\hline The West Australian & 0.462 & & & $-\$ 24,100.00$ & 0.698 \\
\hline Newspaper mean & 0.468 & $\$ 18,050.00$ & 3.574 & $-\$ 25,100.00$ & 1.057 \\
\hline \multicolumn{6}{|l|}{ Radio stations } \\
\hline ABC 891 Adelaide & 0.486 & & & & \\
\hline ABC Radio National & 0.47 & & & & \\
\hline Adelaide 5AA & 0.513 & & & $-\$ 4,845.00$ & 0.809 \\
\hline Brisbane 4BC & 0.524 & & & $\$ 27,593.83$ & 3.260 \\
\hline Brisbane ABC 612 & 0.504 & & & & \\
\hline Melbourne 3AW & 0.509 & & & $-\$ 9,394.00$ & 0.807 \\
\hline Melbourne ABC 774 & 0.499 & & & & \\
\hline Perth 6PR & 0.516 & & & $\$ 2,257.20$ & 1.183 \\
\hline Perth ABC 720 & 0.489 & & & & \\
\hline Sydney 2GB & 0.501 & & & $-\$ 23,100.00$ & 0.000 \\
\hline Sydney 2UE & 0.486 & & & $\$ 50,410.00$ & 3.995 \\
\hline Sydney ABC 702 & 0.478 & & & & \\
\hline Radio mean & 0.498 & & & $\$ 7,147.95$ & 1.676 \\
\hline \multicolumn{6}{|l|}{ Television stations } \\
\hline ABC Channel 2 News & 0.511 & & & & \\
\hline Channel 10 News & 0.49 & $\$ 77,500.00$ & 1.367 & $-\$ 229,000.00$ & 0.898 \\
\hline Channel 7 News & 0.519 & $\$ 14,195.00$ & 1.247 & $\$ 98,698.59$ & 1.279 \\
\hline Channel 9 News & 0.516 & $\$ 31,450.00$ & 1.270 & $\mathrm{~N} / \mathrm{A}$ & $\mathrm{N} / \mathrm{A}$ \\
\hline SBS News & 0.48 & & & $-\$ 128,000.00$ & 0.457 \\
\hline Television mean & 0.503 & $\$ 41,048.33$ & 1.295 & $-\$ 85,800.00$ & 0.878 \\
\hline Spearman rank correlation & & -0.207 & -0.272 & 0.430 & 0.412 \\
\hline with media slant ( $P$-value) & & {$[P=0.542]$} & {$[P=0.418]$} & {$[P=0.075]$} & {$[P=0.101]$} \\
\hline
\end{tabular}

Notes: ' $\mathrm{N} / \mathrm{A}$ ' denotes that data were not available. Blank cells denote zero donations/advertising expenditure, and are not used in estimating the correlations in the final row.

Source: Authors' calculations, based on data from the Australian Electoral Commission.

always editorialise in favour of one side or the other, we separately show Coalition and Labor endorsements (a full breakdown for each election is provided in Table A3). The final column of Table 5 shows the share of Coalition endorsements by each newspaper. On average, 77 per cent of endorsements were for the Coalition. The correlation between the headline ratings and the share of Coalition endorsements is 0.63. For example, the Herald Sun and the West Australian were coded as having the most right-wing headlines, and were also newspapers whose endorsements favoured the Coalition 100 per cent of the time between 1996 and 2007.

Finally, we analyse the relationship between media slant and the financial flows between media outlets and political parties. This is in line with the current literature analysing the 
relationships between financial flows and media behaviour. Reuter and Zitzewitz (2006) investigate the correlation between advertising purchases by financial firms and favourable coverage of these firms. Similarly, Gambaro and Puglisi (2009) analyse the correlation between advertising flows from listed companies and favourable coverage of these companies. Di Tella and Franceschelli (2009) compare the flow of advertising revenues from government to media outlets with coverage of government corruption.

Using figures from the Australian Electoral Commission, Table 6 tabulates two sets of figures. First, we estimate the total political donations given by media proprietors to political parties over the period 1998-1999 to 2006-2007, and estimate the difference between (and ratio of) donations to the Coalition and donations to the Labor Party. We then assign these figures to each media source owned by a given proprietor. ${ }^{27}$ Thus, the figures for The Age and the Sydney Morning Herald are the same, as both are owned by Fairfax, while The Advertiser has a different ratio from The Australian, as both are owned by News Ltd, but The Advertiser recorded a separate donation in its own name. Full details of the donations are provided in Table A4.

We find that all outlets which donated money to political parties gave more to the Coalition, which received a total of $\$ 158,145$ more than Labor. Put differently, the Coalition received $\$ 1.39$ for each dollar given by media proprietors to the Labor Party. Strikingly, no media outlet's proprietors gave more money to Labor than to the Coalition, and for newspapers, the ratio averaged around 3 to 1 .

However, we again find no significant relationship between media slant (as measured in Table 1), and the difference - or ratio - of Coalition funding to Labor funding. This remains true if we use headline coding or editorial endorsements (although this may reflect the small sample of newspapers for which we have donations data).

The right half of Table 6 tabulates financial flows in the opposite direction. Using figures from the 2004 federal election, we calculate the difference between (and ratio of) advertising

\footnotetext{
${ }^{27}$ As media empires contain a large number of outlets (including some not covered by our study), we do not divide the donations by the number of media sources.
}

spending by the Coalition and Labor in each outlet. (More detailed tabulations are provided in Table A5.) In total, the two parties spent around $\$ 6$ million on reported advertising in these outlets during that election. On average, the Coalition outspent Labor on advertising in newspapers, but this is driven by large disparities in the two newspapers where the Coalition spent more: The Advertiser and the Courier Mail. On radio, the Coalition spent more, with at least 3:1 differences in Brisbane $4 \mathrm{BC}$ and Sydney 2UE. Labor spent more on television advertising. We find a significant positive relationship between the advertising spending difference (Coalition minus Labor) and the media slant of a given outlet.

As this is a correlation, interpreting this result is difficult. It is consistent with the simple notion that advertising dollars may be an explicit or implicit payment to proprietors for favourable coverage. However, it is also possible that it would be driven by political parties' observations of media slant. For example, parties might want to avoid placing ads where coverage alongside them is unfavourable. That said, it is also possible that advertising in outlets slanted away from their interests might enable them to target potential swing voters in their direction. Consequently, we state the positive correlation as a result of interest but with specific interpretation requiring more information and study than we are able to provide here.

\section{Discussion and Conclusion}

Media slant is both important and hard to precisely measure. This reflects not only differences in definition, but also the fact that news outlets can differ in the extent of their slant. For example, a television station's slant might change over time, or a paper's news pages might have a different slant from its editorial pages. To capture this, it is useful to employ multiple measures of media slant, and to separately look at slant in content and editorial. Using data from Australia, we employ several metrics for measuring media slant. In terms of content, we find that most media outlets are close to the centre position. Coding media slant using mentions of left-wing and right-wing public intellectuals, we find that only 1 of 27 outlets is significantly distinguishable from the centre (a result that could potentially be a result of chance). We also conclude that there has been no systematic evolution in slant over time. 
Classifying the content of election articles, we find that only one of the nine newspapers is distinguishable from a centrist position.

However, when we look at editorial stances, more dispersion is apparent. Although headlinecoding only reveals one newspaper that is significantly slanted, the pattern of editorial election endorsements is strongly skewed, with 36 of 44 endorsements favouring the Coalition in the period 1996-2007. Consistent with this, we also observe substantial differences in political donations by media proprietors towards political parties, with donation ratios as high as 3:1 in favour of the Coalition.

To the extent that cross-country comparisons are possible, our results suggest that the Australian media - at least in terms of news content are less partisan than their US counterparts. While this could be owing to differences in methodology (and structural differences prevent an exact replication of the US methods), it is also plausible that it reflects the effect of a less competitive media market.

\section{Supporting Information}

Additional supporting information may be found in the online version of this article:

\section{Data S1 Datasets and Codes}

Please note: Wiley-Blackwell is not responsible for the content or functionality of any supporting materials supplied by the authors. Any queries (other than missing material) should be directed to the corresponding author for the article.

\section{REFERENCES}

Anderson, S.P. and McClaren, J. (2009), 'Media Mergers and Media Bias with Rational Consumers', mimeo, Virginia.

Ansolabehere, S., Lessem, R. and Snyder, J.M. (2006), 'The Orientation of Newspaper Endorsements in U.S. Elections, 1940-2002', Quarterly Journal of Political Science, 1, 393-404. Available from: http:/dx.doi.org/10.1561/100.00000009

Baron, D.P. (2006), 'Persistent Media Bias', Journal of Public Economics, 90, 1-35.

Campante, F.R. and Hojman, D. (2010), 'Media and Polarization', HKS Faculty Research Working Paper Series RWP10-002.

Di Tella, R. and Franceschelli, I. (2009), 'Government Advertising and Media Coverage of Corruption Scandals', NBER Working Paper No. 15402.

Durante, R. and Knight, B. (2009), 'Partisan Control, Media Bias and Viewer Responses: Evidence from Berlusconi's Italy', Journal of European Economic Association (forthcoming).
Gambaro, M. and Puglisi, R. (2009), 'What do Ads Buy? Daily Coverage of Listed Companies on the Italian Press', Working Paper Series.

Gentzkow, M. and Shapiro, J. (2006), 'Media Bias and Reputation', Journal of Political Economy, 114, 280-316.

Gentzkow, M. and Shapiro, J. (2008), 'Competition and Truth in the Market for News', Journal of Economic Perspectives, 22, 133-54.

Gentzkow, M. and Shapiro, J. (2010), "What Drives Media Slant? Evidence from U.S. Daily Newspapers', Econometrica, 78, 35-71.

Gentzkow, M., Shapiro, J.M. and Sinkinson, M. (2010), 'The Effect of Newspaper Entry and Exist on Electoral Politics', American Economic Review (forthcoming).

Groseclose, T. and Milyo, J. (2005), 'A Measure of Media Bias', Quarterly Journal of Economics, 120, 1191-237.

Henningham, J. (1995), 'Journalists' Perceptions of Bias', Australian Journalism Review, 17, 28-31.

Ho, D.E. and Quinn, K.M. (2008), 'Measuring Explicit Political Positions of Media', Quarterly Journal of Political Science, 3, 353-77.

Larcinese, V., Puglisi, R. and Snyder, J.M. (2011), 'Partisan Bias in Economic News: Evidence on the Agenda-Setting Behaviour of U.S. Newspapers', Journal of Public Economics, 95, 1178-89.

Millmow, A. (2005), 'Australian Economics in the Twentieth Century', Cambridge Journal of Economics, 29, 1011-26.

Millmow, A. and Courvisanos, J. (2007), 'The Two Tribes of "The Econ": A Study of Economists and Economic Media Commentary in Australia', Economic Papers: A Journal of Applied Economics and Policy, 26, 101-17.

Mullainathan, S. and Shleifer, A. (2005), 'The Market for News', American Economic Review, 95, 1031-53.

Puglisi, R. (2011), 'Being The New York Times: The Political Behaviour of a Newspaper', The B.E. Journal of Economic Analysis \& Policy, 11 (contributions), article 20.

Puglisi, R. and Snyder, J.M. (2010), 'The Centrist U.S. Press', APSA 2010 Annual Meeting Paper. September 2-5, Washington.

Reuter, J. and Zitzewitz, E. (2006), 'Do Ads Influence Editors? Advertising and Bias in the financial media', The Quarterly Journal of Economics, 121, 197-227.

Simons, M. (2007), 'Crikey Bias-o-Meter', Crikey.com. au, June 26

Tabakoff, N. (2009), 'CanWest chief still beaming over Ten Network', The Australian, January 3.

Tim, G. and Jeffrey, M. (2005), 'A Measure of Media Bias', The Quarterly Journal of Economics, 120 (4), 1191-237.

Visontay, M. (2005), 'Australia's Top 100 Public Intellectuals', Sydney Morning Herald, March 12. 


\section{Appendix: Instructions to Headline and Article Coders}

The five individuals who coded articles and headlines from the 2004 election were given the following instruction sheet.

\section{Coding Instructions}

We are carrying out a study of media slant. The aim of this exercise is to look at the content of front-page stories in major Australian newspapers during the 2004 election campaign, and code up how favourable they are to the Coalition or the Labor Party. Our exercise involves separately classifying headlines and articles, as the people who write the headlines are typically not the same people who write the stories.

For each article, we have attempted to remove information that would identify the newspaper, such as the name of the journalist. In some instances, it may be obvious to you which newspaper the article appeared in. In this case, please make a note on your coding sheet, so we are aware of it.

Remember, you are not coding up the facts of the article, but the 'spin' that the newspaper puts on those facts. For example, a party's policy launch is a big news day for that party. But it may be reported very positively, or with some cynicism.

Please code each of the articles or headlines on the following scale:
1 Very pro-Labor
2 Somewhat pro-Labor
3 Middle of the road
4 Somewhat pro-Coalition
5 Very pro-Coalition

If the article does not relate to Labor or the Coalition (e.g. an article that is entirely about the Greens), then please make your best attempt to code it, but also note this point in the spreadsheet.

There are 286 articles/headlines to be coded. Take your time in coding them. You may want to begin by dipping in and reading a random selection of them to familiarise yourself with the 'feel' of the stories.

If you feel that your own political views make it impossible for you to accurately code the stories, please let us know, and you can opt out of the project. It is critical for our purposes that you code articles as objectively as possible.

Two of the articles in the initial sample were from the Sun Herald, but we eventually opted not to use that newspaper.

TABLE A1

Parliamentary Mentions of Public Intellectuals (1996-2007)

\begin{tabular}{lccc}
\hline Name and role & $\begin{array}{c}\text { Total } \\
\text { parliamentary } \\
\text { mentions }\end{array}$ & $\begin{array}{c}\text { Share of } \\
\text { mentions by } \\
\text { Coalition }\end{array}$ & $\begin{array}{c}\text { Test of } \\
\text { equality } \\
(P \text {-value })\end{array}$ \\
\hline Phillip Adams - broadcaster & 26 & 0.65 & 0.17 \\
Richard Allsop - Institute for Public Affairs & 0 & 1.00 & 0.47 \\
Dennis Altman - social scientist & 1 & 0.50 & 1.00 \\
Ien Ang - cultural studies & 0 & 0.80 & 0.05 \\
Robyn Archer - theatre & 2 & 0.00 & 0.50 \\
Bettina Arndt - sexual politics & 10 & 0.25 & 0.63 \\
Julia Baird - journalist & 2 & 0.89 & 0.02 \\
Geremie Barme - China scholar & 0 & 0.10 & 0.02 \\
Greg Barns - politics & 4 & & \\
Marie Bashir - civil society & 9 & 0 & 0.03 \\
Roger Bate - Centre for Independent Studies & 10 & 0.73 & 0.60 \\
Larissa Behrendt - Aboriginal lawyer & 0 & 0.67 & 0.35 \\
Coral Bell - international affairs & 26 & 0.55 & 0.50 \\
Chris Berg - Institute for Public Affairs & 3 & 0.00 & 0.50 \\
Geoffrey Blainey - historian & 56 & & \\
Veronica Brady - writer & 2 & 0.00 & \\
Frank Brennan - social justice & 0 & & \\
Judith Brett - political scientist & 2 & & \\
Katharine Brisbane - theatre, publishing & & & \\
Alison Broinowski - foreign policy & & & \\
\hline
\end{tabular}


Table A1

(Continued)

\begin{tabular}{|c|c|c|c|}
\hline Name and role & $\begin{array}{c}\text { Total } \\
\text { parliamentary } \\
\text { mentions }\end{array}$ & $\begin{array}{l}\text { Share of } \\
\text { mentions by } \\
\text { Coalition }\end{array}$ & $\begin{array}{c}\text { Test of } \\
\text { equality } \\
(P \text {-value })\end{array}$ \\
\hline Ron Brunton - anthropologist & 8 & 1.00 & 0.00 \\
\hline Jennifer Buckingham - Centre for Independent Studies & 2 & 0.50 & 1.00 \\
\hline Julian Burnside - lawyer & 5 & 0.00 & 0.06 \\
\hline Helen Caldicott - anti-nuclear campaigner & 0 & & \\
\hline Peter Carey - writer & 3 & 0.33 & 1.00 \\
\hline Robert Carling - Centre for Independent Studies & 0 & & \\
\hline John Carroll - sociologist & 3 & 0.33 & 1.00 \\
\hline Hilary Charlesworth - legal academic & 7 & 0.43 & 1.00 \\
\hline Max Charlesworth - bioethicist & 1 & 1.00 & 0.47 \\
\hline John Clarke - satirist & 5 & 0.00 & 0.06 \\
\hline Inga Clendinnen - historian & 1 & 1.00 & 0.47 \\
\hline Tony Coady - ethicist & 2 & 0.00 & 0.50 \\
\hline John Coetzee - writer & 0 & & \\
\hline Peter Conrad - writer & 0 & & \\
\hline Eva Cox - feminist & 9 & 0.56 & 0.74 \\
\hline Peter Craven - critic & 1 & 0.00 & 1.00 \\
\hline Stephen Crittenden - religious broadcaster & 1 & 1.00 & 0.47 \\
\hline Peter Cullen - environmental academic & 27 & 0.52 & 1.00 \\
\hline Anne Curthoys - historian & 0 & & \\
\hline Paul Davies - scientist & 3 & 1.00 & 0.10 \\
\hline Mark Davis - cultural critic & 1 & 1.00 & 0.47 \\
\hline Glyn Davis - education & 18 & 0.56 & 0.49 \\
\hline William Deane - legal advocate & 109 & 0.31 & 0.00 \\
\hline Robert Dessaix - broadcaster, writer & 0 & & \\
\hline Julian Disney - social justice & 6 & 0.17 & 0.22 \\
\hline Mick Dodson - Aboriginal advocate & 58 & 0.26 & 0.00 \\
\hline Peter Doherty - scientist & 33 & 0.52 & 0.86 \\
\hline Michael Duffy - commentator & 11 & 0.73 & 0.13 \\
\hline Bob Ellis - writer & 4 & 0.25 & 0.63 \\
\hline Richard Flanagan - writer & 0 & & \\
\hline Tim Flannery - scientist & 21 & 0.48 & 1.00 \\
\hline Morag Fraser - editor, writer & 0 & & \\
\hline Stephan Freitag - Centre for Independent Studies & 0 & & \\
\hline Raimond Gaita - philosopher & 1 & 0.00 & 1.00 \\
\hline Ross Garnaut - economist & 41 & 0.41 & 0.35 \\
\hline Helen Garner - writer & 0 & & \\
\hline Germaine Greer - feminist & 4 & 0.75 & 0.35 \\
\hline Ghassan Hage - anthropologist & 0 & & \\
\hline Gideon Haigh - journalist & 0 & & \\
\hline Clive Hamilton - economist & 24 & 0.42 & 0.42 \\
\hline Owen Harries - international affairs & 3 & 0.33 & 1.00 \\
\hline Gerard Henderson - commentator & 36 & 0.22 & 0.00 \\
\hline John Hirst - historian & 13 & 1.00 & 0.00 \\
\hline Geoff Hogbin - Centre for Independent Studies & 0 & & \\
\hline Jim Hoggett - Institute for Public Affairs & 1 & 0.00 & 1.00 \\
\hline Donald Horne - civil society & 8 & 0.38 & 0.73 \\
\hline Jackie Huggins - Aboriginal historian & 13 & 0.46 & 1.00 \\
\hline Robert Hughes - art critic & 5 & 0.20 & 0.38 \\
\hline Helen Hughes - economist & 13 & 1.00 & 0.00 \\
\hline Barry Humphries - satirist & 3 & 0.67 & 0.60 \\
\hline Ken Inglis - historian & 3 & 0.00 & 0.25 \\
\hline
\end{tabular}


TABLE A1

(Continued)

\begin{tabular}{|c|c|c|c|}
\hline Name and role & $\begin{array}{c}\text { Total } \\
\text { parliamentary } \\
\text { mentions }\end{array}$ & $\begin{array}{c}\text { Share of } \\
\text { mentions by } \\
\text { Coalition }\end{array}$ & $\begin{array}{c}\text { Test of } \\
\text { equality } \\
(P \text {-value })\end{array}$ \\
\hline Linda Jaivin - writer & 0 & & \\
\hline Clive James - critic & 0 & & \\
\hline Paul Kelly - journalist & 104 & 0.62 & 0.00 \\
\hline Michael Kirby - judge & 137 & 0.33 & 0.00 \\
\hline Rachael Kohn - religious affairs & 0 & & \\
\hline Karl Kruszelnicki - scientist & 2 & 0.00 & 0.50 \\
\hline Marcia Langton - Aboriginal academic & 10 & 0.70 & 0.53 \\
\hline Stephen Leeder - public health & 9 & 0.78 & 0.09 \\
\hline Michael Leunig - cartoonist & 1 & 1.00 & 0.47 \\
\hline Greg Lindsay - Centre for Independent Studies & 1 & 1.00 & 0.47 \\
\hline Simon Longstaff - ethicist & 7 & 0.43 & 1.00 \\
\hline Ian Lowe - environmental scientist & 8 & 0.13 & 0.07 \\
\hline Catherine Lumby - gender studies & 2 & 0.00 & 0.50 \\
\hline Stuart Macintyre - historian & 7 & 0.43 & 1.00 \\
\hline Hugh Mackay - social affairs & 18 & 0.78 & 0.02 \\
\hline Barry Maley - Centre for Independent Studies & 2 & 1.00 & 0.22 \\
\hline David Malouf - writer & 7 & 0.71 & 0.27 \\
\hline Robert Manne - political scientist & 13 & 0.23 & 0.10 \\
\hline Jennifer Marohasy - Institute for Public Affairs & 3 & 1.00 & 0.10 \\
\hline David Marr - journalist & 18 & 0.00 & 0.00 \\
\hline Sophie Masson - writer & 2 & 1.00 & 0.22 \\
\hline Robert May - scientist & 3 & 0.67 & 0.60 \\
\hline Wendy McCarthy - public affairs & 7 & 1.00 & 0.01 \\
\hline John McDonald - art critic & 0 & & \\
\hline Paddy McGuinness - commentator & 8 & 0.50 & 1.00 \\
\hline Andrew McIntyre - Institute for Public Affairs & 0 & & \\
\hline Humphrey McQueen - historian & 1 & 0.00 & 1.00 \\
\hline Bill Mitchell - architect & 0 & & \\
\hline Drusilla Modjeska - writer & 0 & & \\
\hline Alan Moran - Institute for Public Affairs & 6 & 0.50 & 1.00 \\
\hline Meaghan Morris - cultural critic & 0 & & \\
\hline Glenn Murcutt - architect & 0 & & \\
\hline Les Murray - poet & 20 & 0.10 & 0.00 \\
\hline Mike Nahan - Institute for Public Affairs & 2 & 1.00 & 0.22 \\
\hline Richard Neville - commentator & 0 & & \\
\hline Andrew Norton - Centre for Independent Studies & 4 & 0.50 & 1.00 \\
\hline Gustav Nossal - scientist & 57 & 0.47 & 1.00 \\
\hline Noel Pearson - Aboriginal advocate & 135 & 0.67 & 0.00 \\
\hline Christopher Pearson - columnist & 11 & 0.55 & 0.77 \\
\hline George Pell - church leader & 39 & 0.56 & 0.26 \\
\hline Ken Phillips - Institute for Public Affairs & 4 & 1.00 & 0.05 \\
\hline Barbara Pocock - social scientist & 8 & 0.00 & 0.01 \\
\hline Peter Porter - poet & 0 & & \\
\hline Elspeth Probyn - gender studies & 0 & & \\
\hline Michael Pusey - sociologist & 2 & 0.00 & 0.50 \\
\hline John Quiggin - economist & 21 & 0.29 & 0.12 \\
\hline Phil Rennie - Centre for Independent Studies & 0 & & \\
\hline Henry Reynolds - historian & 5 & 0.40 & 1.00 \\
\hline John Roskam - Institute for Public Affairs & 3 & 0.67 & 0.60 \\
\hline Guy Rundle - satirist, critic & 2 & 1.00 & 0.22 \\
\hline Pierre Ryckmans - writer & 1 & 0.00 & 1.00 \\
\hline Peter Saunders - Centre for Independent Studies & 6 & 0.67 & 0.43 \\
\hline
\end{tabular}


TABLE A1

(Continued)

\begin{tabular}{|c|c|c|c|}
\hline Name and role & $\begin{array}{c}\text { Total } \\
\text { parliamentary } \\
\text { mentions }\end{array}$ & $\begin{array}{c}\text { Share of } \\
\text { mentions by } \\
\text { Coalition }\end{array}$ & $\begin{array}{c}\text { Test of } \\
\text { equality } \\
(P \text {-value })\end{array}$ \\
\hline Peter Saunders - UNSW & 4 & 0.25 & 0.63 \\
\hline Julianne Schultz - editor & 3 & 0.67 & 0.60 \\
\hline Arti Sharma - Centre for Independent Studies & 0 & & \\
\hline Paul Sheehan - journalist & 13 & 0.85 & 0.01 \\
\hline Peter Singer - philosopher & 1 & 0.00 & 1.00 \\
\hline Bernard Smith - art historian & 2 & 0.50 & 1.00 \\
\hline Gaurav Sodhi - Centre for Independent Studies & 0 & & \\
\hline Jim Spigelman - judge & 1 & 0.00 & 1.00 \\
\hline Louise Staley - Institute for Public Affairs & 0 & & \\
\hline Fiona Stanley - scientist & 23 & 0.65 & 0.10 \\
\hline Kirsten Storry - Centre for Independent Studies & 0 & & \\
\hline Hugh Stretton - historian & 0 & & \\
\hline Anne Summers - feminist & 6 & 0.00 & 0.03 \\
\hline McKenzie Wark - cultural critic & 0 & & \\
\hline Don Watson - writer & 8 & 0.63 & 0.49 \\
\hline Margaret Wertheim - science writer & 1 & 1.00 & 0.47 \\
\hline Robyn Williams - science broadcaster & 2 & 0.00 & 0.50 \\
\hline George Williams - legal academic & 46 & 0.26 & 0.00 \\
\hline David Williamson - playwright & 10 & 0.20 & 0.12 \\
\hline Tim Wilson - Institute for Public Affairs & 0 & & \\
\hline Keith Windschuttle - critic/historian & 6 & 0.33 & 0.69 \\
\hline Susan Windybank - Centre for Independent Studies & 1 & 0.00 & 1.00 \\
\hline Tim Winton - writer & 4 & 0.25 & 0.63 \\
\hline Peter Yu - Aboriginal affairs & 30 & 0.30 & 0.07 \\
\hline
\end{tabular}

Notes: Roles are coded by Visontay (2005), except in the case of researchers at the Centre for Independent Studies or the Institute of Public Affairs, which are separately noted. Total parliamentary mentions are the total mentions in both chambers by major party parliamentarians between January 1996 and June 2007. Share of mentions by Coalition is the share of mentions that came from Coalition parliamentarians (the remainder being Labor mentions). Test of equality is a binomial probability test of the hypothesis that the share of Coalition mentions is equal to 0.47 , which is the mean across all public intellectuals.

TABLE A2

Full Frequency Distribution of Article and Headline Coding, by Newspaper

\begin{tabular}{|c|c|c|c|c|c|}
\hline & $\begin{array}{c}\text { Very } \\
\text { pro-Labor }\end{array}$ & $\begin{array}{l}\text { Somewhat } \\
\text { pro-Labor }\end{array}$ & $\begin{array}{l}\text { Middle of } \\
\text { the road }\end{array}$ & $\begin{array}{c}\text { Somewhat } \\
\text { pro-Coalition }\end{array}$ & $\begin{array}{c}\text { Very } \\
\text { pro-Coalition }\end{array}$ \\
\hline \multicolumn{6}{|l|}{ Article coding } \\
\hline Canberra Times & 0.088 & 0.218 & 0.353 & 0.247 & 0.094 \\
\hline Daily Telegraph & 0.112 & 0.216 & 0.312 & 0.240 & 0.120 \\
\hline Herald Sun & 0.091 & 0.164 & 0.509 & 0.164 & 0.073 \\
\hline Sydney Morning Herald & 0.056 & 0.244 & 0.388 & 0.225 & 0.087 \\
\hline The Advertiser & 0.059 & 0.200 & 0.400 & 0.271 & 0.071 \\
\hline The Age & 0.124 & 0.276 & 0.373 & 0.178 & 0.049 \\
\hline The Australian & 0.091 & 0.266 & 0.316 & 0.244 & 0.084 \\
\hline The Courier Mail & 0.080 & 0.307 & 0.293 & 0.267 & 0.053 \\
\hline The West Australian & 0.062 & 0.285 & 0.292 & 0.292 & 0.069 \\
\hline Mean for articles & 0.088 & 0.253 & 0.345 & 0.237 & 0.077 \\
\hline \multicolumn{6}{|l|}{ Headline coding } \\
\hline Canberra Times & 0.106 & 0.212 & 0.447 & 0.176 & 0.059 \\
\hline Daily Telegraph & 0.176 & 0.160 & 0.352 & 0.240 & 0.072 \\
\hline Herald Sun & 0.055 & 0.109 & 0.564 & 0.109 & 0.164 \\
\hline Sydney Morning Herald & 0.087 & 0.219 & 0.369 & 0.231 & 0.094 \\
\hline
\end{tabular}


TABle A2

(Continued)

\begin{tabular}{lccccc}
\hline & $\begin{array}{c}\text { Very } \\
\text { pro-Labor }\end{array}$ & $\begin{array}{c}\text { Somewhat } \\
\text { pro-Labor }\end{array}$ & $\begin{array}{c}\text { Middle of } \\
\text { the road }\end{array}$ & $\begin{array}{c}\text { Somewhat } \\
\text { pro-Coalition }\end{array}$ & $\begin{array}{c}\text { Very } \\
\text { pro-Coalition }\end{array}$ \\
\hline The Advertiser & 0.094 & 0.200 & 0.341 & 0.247 & 0.118 \\
The Age & 0.093 & 0.284 & 0.378 & 0.187 & 0.058 \\
The Australian & 0.063 & 0.237 & 0.381 & 0.237 & 0.081 \\
The Courier Mail & 0.073 & 0.307 & 0.353 & 0.200 & 0.067 \\
The West Australian & 0.069 & 0.231 & 0.338 & 0.254 & 0.108 \\
Mean for headlines & 0.089 & 0.232 & 0.382 & 0.215 & 0.082 \\
\hline
\end{tabular}

Notes: Articles and headlines were published on the front page during the 2004 election campaign. Rows sum across to 100 per cent.

TABLE A3

Newspaper Editorial Endorsements by Election

\begin{tabular}{|c|c|c|c|c|c|}
\hline & 1996 election & 1998 election & 2001 election & 2004 election & 2007 election \\
\hline Australian Financial Review & Coalition & Coalition & Coalition & Coalition & Coalition \\
\hline Canberra Times & Neither & Neither & Neither & Labor & Labor \\
\hline Daily Telegraph & Labor & Coalition & Coalition & Coalition & Labor \\
\hline Herald Sun & Coalition & Coalition & Coalition & Coalition & Coalition \\
\hline Sydney Morning Herald & Coalition & Coalition & Coalition & Neither & Labor \\
\hline The Advertiser & Coalition & Coalition & Coalition & Coalition & Coalition \\
\hline The Age & Coalition & Coalition & Labor & Coalition & Neither \\
\hline The Australian & Neither & Coalition & Coalition & Coalition & Labor \\
\hline The Courier Mail & Coalition & Coalition & Coalition & Coalition & Labor \\
\hline The West Australian & Coalition & Coalition & Coalition & Coalition & Coalition \\
\hline
\end{tabular}

Source: Authors' tabulations.

TABLE A4

Donations by Media Proprietors

\begin{tabular}{|c|c|c|c|}
\hline Donor & $\begin{array}{c}\text { Media outlets owned } \\
\text { (and covered by our study) }\end{array}$ & $\begin{array}{l}\text { Donation to } \\
\text { Coalition }\end{array}$ & $\begin{array}{l}\text { Donation to } \\
\text { Labor }\end{array}$ \\
\hline Canwest Pacific Communications Pty Ltd & Channel 10 & $\$ 50,000$ & $\$ 50,000$ \\
\hline John Fairfax Holdings Ltd & $\begin{array}{l}\text { Australian Financial Review, } \\
\text { Sydney Morning Herald, The Age }\end{array}$ & $\$ 32,800$ & $\$ 12,500$ \\
\hline Network Ten Ltd & Channel 10 & $\$ 238,500$ & $\$ 161,000$ \\
\hline News Ltd & $\begin{array}{l}\text { Daily Telegraph, Herald Sun, } \\
\text { The Advertiser, The Australian, } \\
\text { The Courier Mail }\end{array}$ & $\$ 22,200$ & $\$ 5000$ \\
\hline Nine Network Australia & Channel 9 & $\$ 25,950$ & $\$ 16,500$ \\
\hline Prime Television (Holdings) Pty Ltd & Channel 7 & $\$ 59,500$ & $\$ 50,000$ \\
\hline Publishing and Broadcasting Ltd & Channel 9 & $\$ 122,000$ & $\$ 100,000$ \\
\hline Seven Network & Channel 7 & $\$ 12,195$ & $\$ 7500$ \\
\hline The Advertiser & The Advertiser & $\$ 0$ & $\$ 2500$ \\
\hline
\end{tabular}

Notes: Assignment of owners to outlets is based on majority holdings during the period 1999-2007. During this period, Canwest owned 56 per cent of Channel 10. Fairfax's acquisition of the radio stations formerly owned by Southern Cross Broadcasting (including 2UE Sydney, 3AW Melbourne, 4BC Brisbane and 6PR Perth) and its acquisition of the Canberra Times (as a result of the merger with Rural Press) both took place in 2007; so, we do not include these ownership links in our analysis.

Source: Donations data are from the Australian Electoral Commission, covering the financial years 1998-1999 to $2006-2007$. Figures were published online at: http://www.democracy4sale.org/. We use that website's classification of 'Media/ Communications', and then searched each company's media holdings. 
TABLE A5

Advertising Expenditure in the 2004 Election

\begin{tabular}{|c|c|c|c|c|}
\hline & $\begin{array}{l}\text { Total Coalition } \\
\text { ad spending }\end{array}$ & $\begin{array}{l}\text { Total Australian } \\
\text { Labor Party (ALP) } \\
\text { ad spending }\end{array}$ & $\begin{array}{c}\text { Total Coalition } \\
\text { ad discount }\end{array}$ & $\begin{array}{l}\text { Total ALP } \\
\text { ad discount }\end{array}$ \\
\hline \multicolumn{5}{|l|}{ Newspapers } \\
\hline Australian Financial Review & $\$ 0.00$ & $\$ 0.00$ & $\$ 0.00$ & $\$ 0.00$ \\
\hline Canberra Times & $\$ 19,897.72$ & $\$ 37,893.51$ & $\$ 0.00$ & $\$ 0.00$ \\
\hline Sydney Morning Herald & $\$ 153,802.88$ & $\$ 267,431.16$ & $\$ 4730.88$ & $\$ 0.00$ \\
\hline Daily Telegraph & $\$ 59,337.90$ & $\$ 116,591.86$ & $\$ 0.00$ & $\$ 0.00$ \\
\hline Herald Sun & $\$ 88,234.40$ & $\$ 109,341.95$ & $\$ 0.00$ & $\$ 0.00$ \\
\hline The Advertiser & $\$ 33,387.58$ & $\$ 11,835.32$ & $\$ 0.00$ & $\$ 0.00$ \\
\hline The Age & $\$ 103,359.00$ & $\$ 119,767.50$ & $\$ 3973.20$ & $\$ 0.00$ \\
\hline \multicolumn{5}{|l|}{ The Australian } \\
\hline The Courier Mail & $\$ 6893.22$ & $\$ 4161.06$ & $\$ 0.00$ & $\$ 0.00$ \\
\hline The West Australian & $\$ 55,641.41$ & $\$ 79,702.03$ & $\$ 0.00$ & $\$ 0.00$ \\
\hline \multicolumn{5}{|l|}{ Radio stations } \\
\hline Sydney 2UE & $\$ 67,240.00$ & $\$ 16,830.00$ & $\$ 0.00$ & $\$ 0.00$ \\
\hline Sydney 2GB & $\$ 0.00$ & $\$ 23,134.32$ & $\$ 0.00$ & $\$ 2336.80$ \\
\hline \multicolumn{5}{|l|}{ Sydney ABC 702} \\
\hline Perth 6PR & $\$ 14,612.40$ & $\$ 12,355.20$ & $\$ 1476.00$ & $\$ 1248.00$ \\
\hline \multicolumn{5}{|l|}{ Perth ABC 720} \\
\hline Melbourne 3AW & $\$ 39,226.00$ & $\$ 48,620.00$ & $\$ 0.00$ & $\$ 0.00$ \\
\hline \multicolumn{5}{|l|}{ Melbourne ABC 774} \\
\hline Adelaide 5AA & $\$ 20,525.00$ & $\$ 25,370.00$ & $\$ 0.00$ & $\$ 0.00$ \\
\hline Brisbane $4 \mathrm{BC}$ & $\$ 39,803.50$ & $\$ 12,209.67$ & $\$ 0.00$ & $\$ 0.00$ \\
\hline \multicolumn{5}{|l|}{ ABC Radio National } \\
\hline \multicolumn{5}{|l|}{ ABC 891 Adelaide } \\
\hline \multicolumn{5}{|l|}{ Brisbane ABC 612} \\
\hline \multicolumn{5}{|l|}{ TV stations } \\
\hline Channel 10 & $\$ 2,011,556.00$ & $\$ 2,240,159.00$ & $\$ 0.00$ & $\$ 0.00$ \\
\hline Channel 7 & $\$ 452,871.10$ & $\$ 354,172.50$ & $\$ 0.00$ & $\$ 0.00$ \\
\hline \multicolumn{5}{|l|}{ Channel 9} \\
\hline SBS & $\$ 107,479.00$ & $\$ 235,018.00$ & $\$ 0.00$ & $\$ 0.00$ \\
\hline \multicolumn{5}{|l|}{ ABC Channel 2} \\
\hline Total & $\$ 3,273,867.11$ & $\$ 3,714,593.08$ & $\$ 10,180.08$ & $\$ 3584.80$ \\
\hline
\end{tabular}

Note: Figures for The Australian and Channel 9 were not reported.

Source: Authors' calculations, based on data available on the Australian Electoral Commission's website. 